\title{
USING ECOSYSTEM-BASED AND TRADITIONAL LAND-USE PLANNING TO CONSERVE GREENSPACE
}

\author{
by W.F. Elmendorf' and A.E. Luloff ${ }^{2}$
}

\begin{abstract}
When conserved in greenspace, natural systems-forests, stream corridors, and chaparral-provide many benefits to people and communities. Conserving greenspace, then, requires traditional land-use planning and regulation, which provides local governments powerful tools and processes. Greenspace conservation can be hampered by a lack of intermunicipal cooperation, disregard for natural systems within the planning process, and concems for the taking of private property rights. Because of a broadscale approach, an ecosystem-based approach to community forestry can support traditional land-use planning in conservation efforts across the many landscapes and through the people involved in community development. Use of an ecosystem approach has problems, however, including the building of cooperation and partnership between multiple jurisdictions and agencies. Furthermore, a lack of awareness and involvement by community foresters and arborists may impede the success of either traditional or ecosystem planning approaches in conserving greenspace.
\end{abstract}

\section{CONSERVING GREENSPACE BENEFITS COMMUNITY}

Greenspace conjures visions of large, essentially undeveloped landscapes such as stream corridors, woodlots, and agricultural and forested lands. Greenspace can be conserved during development in both working and passive landscapes to provide economic, environmental, and social benefits for communities. The raw materials and places for forestry, agriculture, and tourism businesses are found in greenspaces.

The literature has shown that greenspace increases the value and marketability of homes and other real estate and attracts new and progressive businesses to communities (Center for the Study of Law and Politics 1991; National Park Service 1992). Landscape-level benefits include conservation of wildlife habitats, air and watersheds, and quality recreational and educational experiences (McHarg 1992; USDA Forest Service 1993). Researchers such as Simpson (1998) and McPherson (1998) have studied the interconnectedness of vegetation across urban and suburban landscapes and the positive impacts of natural systems, or green infrastructure, on energy use, cooling, and carbon dioxide storage.

Greenspace's important social and psychological values include tranquillity, exploration, richness, wonderment, beauty, and solace (Luloff et al. 1993). Dwyer et al. (1992) describe deep psychological ties between people and urban forests, and the significant roles and important meanings of urban forests to people, including as the embodiment of shared and structured symbols. Such symbols (e.g., historic landscapes) provide comfort and continuity to people during periods of community growth.

Greenspace also can serve as a buffer among different land uses and can be used to break sprawling development (Simon et al. 1993). Providing natural boundaries to development enhances neighborhood and community identity, which increases both social interaction and the psychological identification with a locality, helping people feel more a part of their home community (Hawley 1950; Wilkinson 1991).

\section{COSTS OF NOT PLANNING FOR GREENSPACE CONSERVATION}

Economic and social changes, particularly after World War II, continue to radically alter landscapes in the United States (Lewis 1993). Some of the more significant changes include development of masstransportation systems, improvements in communications and information technologies, a shift from an industrial- to a service-based economy, and the growing suburbanization of people and capital. All of these changes have fueled a new type of development in the United States. This development is spatially represented by the American strip mall and horizontally sprawling suburban and rural settlements that Lewis (1993) termed the "Gallactic City." 
Sprawling housing and development infrastructure have been blamed for numerous environmental problems, including decreased biodiversity, loss of recreational opportunities, contamination of aquifers, and the fragmentation, isolation, and destruction of working and nonworking landscapes such as wildlife habitat (Harper and Propst 1990; Boughton et al. 1991; Falk et al. 1992; Yaro et al. 1993; Hylton 1995). Further, the costs of not planning for greenspace conservation include increased public costs for services (including education), increased public costs for disasters (including fire and flood), decreased community image and reputation, lower property values, and increased public anxiety (Wilkinson 1991). Furthermore, because of both increasing land values and competition for land purchase, failure to plan for and conserve greenspace early on in community development amplifies the complexities and costs of later efforts.

Opportunities for greenspace continue to be compromised or eliminated by unplanned development and sprawl, furthered by a lack of intermunicipal cooperation (Arendt 1994, 1997). Concerned about the future of community greenspace and trees, Clark et al. (1997) described a model for urban forest sustainability. Although both local and broader-scale land-use planning and regulation were considered in this inclusive model, they deserve more attention as powerful processes for greenspace and tree conservation.

\section{WHY BECOME INVOLVED IN PLANNING}

Community forestry can be separated into two fields. Although not mutually exclusive, one field focuses more on systems management and maintenance of public trees and landscapes. The other field focuses on planning for and managing natural systems associated with developing and existing communities. This distinction in community forestry is demonstrated in the content of current journal articles, in respected textbooks (cf. Miller 1998), and in the funding and program strategies of state and federal agencies.

For those interested in planning for and managing natural systems, land-use planning and regulation can provide processes for planning for and regulating how natural systems in urban, suburban, and/or rural landscapes can be organized and conserved in the face of development and growth pressures. Land-use planning and regulation can be used in planning for and providing continuity and a logical, optimal structure for natural systems associated with human settlements. On the other hand, for those interested in the systems management and maintenance of public trees, land-use planning and regulation can be used to ensure planting and preservation of trees in parking lots, subdivisions, and other developments.

As a practical matter, business opportunities accompany the conservation of greenspace and trees, through land-use planning and regulation. These opportunities include completing natural resource inventories; performing tree evaluations and using other assessment tools; completing tree preservation and other conservation plans; consulting on tree preservation ordinances and other policy vehicles; and developing and installing tree preservation and other arboricultural devices. Land-use planning and regulation can be used to conserve a green infrastructure upon which sustainable management and maintenance functions can be applied by community foresters and arborists. Finally, community foresters and arborists can improve the process of community development by becoming more aware of and involved in land-use planning and decision making.

\section{TRADITIONAL LAND-USE PLANNING: A LOCAL MODEL FOR GREENSPACE CONSERVATION}

Although U.S. communities have used planning in some form or manner since their inception, especially to promote health, safety, welfare, and spirituality, land-use planning is a relatively new governmental force shaped by a number of circumstances. At the end of the nineteenth century, U.S. cities faced dramatic increases in industry and population from inmigration. Decreases in the quality of life and environment caused by pollution from an increasing population and growing industry were commonplace in cities during the Industrial Revolution.

Authors credit the 1893 Colombian Exposition in Chicago with providing the impetus towards land-use planning in the United States. The exposition showed millions of fairgoers a model city with planned locations for residential and other land uses, and numerous greenspaces, riding and walking paths, greenways, and trees (Wilson 1989). Further reaction to a perceived decline in quality of life and environment led to the creation of the City Beautiful Move- 
ment (1890-1920), which recognized and promoted the importance of beautiful, healthy, and functional cities. Adherents demanded a reorientation of public thought and action towards public beauty, promoting not only the planning of towns and cities, but the conservation of parks and greenways, and the selection, planting, and maintenance of trees (Wilson 1989). In the 1920s, the U.S. Department of Commerce provided states with two model laws, the Standard Zoning Enabling Act and the Standard City Planning Enabling Act. Both models were to be used by states to develop legislation allowing local governments to perform land-use planning and establish regulations. Thus, land-use planning as a governmental force is relatively new in shaping American landscapes and communities.

Traditional land-use planning and regulation can conserve greenspace and have tremendous impacts on the social characteristics of a community through different functions, such as forming a comprehensive plan; formulating and updating zoning and other ordinances; coordinating local development activities by reviewing and modifying proposed land development; collecting, analyzing, and providing information to guide decision making; and empowering public involvement in community development decisions through public education, hearings, and committees.

The comprehensive plan and zoning and subdivision ordinances are important planning tools. The former is a growth management plan used to picture future growth. A comprehensive plan provides guidance for future growth and development by identifying and considering community development alternatives. In statements of vision, goals, and strategies for community development, the comprehensive plan outlines what needs to be done, and when and how it will be done. The comprehensive plan provides a logical basis for zoning and other ordinances and a long-term guide for use in understanding and reviewing current development proposals.

Zoning is not planning but an implementation tool for the comprehensive plan. Zoning and subdivision ordinances are enacted after a comprehensive plan is completed to help ensure that the location and types of land uses outlined in the plan come to realization. Conventional zoning ordinances specify the height of buildings, the percentages of a parcel that may be developed, the density of development, and the use of land. Subdivision ordinances provide standards for subdivision design, such as a sequence for permit processing, and required improvements for adequate lots, such as utilities, streets, and sewage.

In some municipalities, such as Boulder, Colorado, and Thousand Oaks, California, land-use planning and regulation, coupled with dedicated public involvement, have worked to conserve large greenspace systems, but these may be the exception rather than the rule. Although land-use planners have long promoted conservation of greenspace, some believe that the benefits of such systems to the quality of life and the environment continue to be ignored in development and development planning (Lemonides and Young 1978; Luloff and Hodges 1992; McHarg 1992; Arendt 1997). In Pennsylvania, surveys of 50 land-use planners, planning commissioners, and community leaders who attended greenspace conservation workshops were conducted to provide information on barriers to land-use planning and regulation to conserve greenspace. Barriers identified in this survey include the following:

- The autonomous history of Pennsylvania's 2,567 municipalities, which leads to difficulty in and opposition to developing multijurisdictional cooperation and partnerships. There are few examples of working relationships among planning departments that would facilitate broad-scale planning.

- A lack of desire by municipalities to complete natural resource and other inventories that supply information essential for comprehensive planning. Greenspace conservation often is a residual of development planning.

- Legislation that enables, but does not require, municipalities to develop comprehensive plans. Planning is voluntary, and municipalities often lack the desire or ability to develop comprehensive plans. Municipalities practice "negative planning" by enacting ordinances and reviewing current proposals with no comprehensive plan to provide vision and direction for development.

- Opposition to reviewing and revising inadequate zoning and subdivision ordinances. 
Conventional zoning most often establishes single lot size minimums on property. The number of lots basically becomes the size of the property divided by the minimum lot size. Such "cookie-cutter" zoning encourages the maximum number of minimum-sized lots, not the conservation of natural features. Conventional subdivision ordinances often result in development of strips of lots along streets and as many lots as possible on a piece of property.

- A lack of professional planning staff and local expertise in growing rural areas causes poor development review and modification; also, there is rapid turnover among volunteer planning commissioners, and leaders may have personal rather than public agendas.

- A lack of municipal funds for capital projects such as greenspace acquisition and comprehensive planning.

- A lack of education and information on the benefits of multijurisdictional cooperation, a quality natural environment, and the costs of poor land-use planning.

- A lack of awareness and involvement of residents in community decision making.

Barriers identified in this survey were similar to those identified by other authors (cf. Luloff and Hodges 1992). Besides the fact that planning often does not take place, significant concerns for using the principles of land-use planning and regulation to conserve greenspace include ignorance of nature within the planning process, a localized orientation of planning to individual municipalities, and a lack of cooperation between municipalities. The latter is important because ecological, social, and economic systems are often large scale and exist across jurisdictional and property lines. Thus, efforts at land use and development in one jurisdiction can have serious impacts on the ecological, social, and economic systems in others. When considering quality human recreational experiences and large-scale systems such as wildlife habitat and watersheds, land-use planning that considers both local and broader-scale elements provides a critical hierarchy for engaging in sustainable community development (Freudenburg and Keating 1985).

\section{AN ECOSYSTEM-BASED APPROACH}

An ecosystem-based approach (EBA) to community forestry (USDA Forest Service 1994) was developed to promote and support community forestry's involvement in planning for broad-scale environmental and social issues. Although EBA is noted as a revolutionary systems process, in reality it is similar to the conservation systems approach promoted by Aldo Leopold in the 1940s. Leopold insisted on setting specific standards of conservation for areas through careful observation, historical study, and scientific research, and then monitoring and evaluating impacts and effects. Two attributes of EBA are not included in Leopold's concept: multijurisdictional/agency planning and considering social systems an important component of environmental systems. As illustrated in Table 1, EBA is an expanded land-use planning process designed to facilitate the integration of broadscale natural and social systems in community development. Table 2 provides a summary of important differences between an EBA approach and traditional land-use planning.

\section{Ecosystem Themes}

A number of themes play central roles in the EBA approach. These include ecological rather than jurisdictional boundaries, ecological integrity, data collection and land-use monitoring, interagency cooperation, intermunicipal cooperation, organizational change, humanity in nature, and empowerment and inclusiveness of people.

A pervasive theme of EBA is environmental justice, which can be defined as the provision of a safe living environment for all people, with equal access to healthy natural systems and empowerment of marginalized people in environmental decision making. By identifying who is important, interested, and impacted by land-use decisions, EBA provides a planning process that can confront discrimination, racism, classism, ageism, and other issues of equity. This process also can be used to help realize a principle of democratic government-that people have the right to participate in decisions that affect their well-being. By aggressively empowering people's involvement, EBA increases the opportunities for open participation in decision making by those who suffer discrimina- 
Table 1. A process for an ecosystem-based approach to community forestry.

Step 1. Initiate program

Identify opportunity or problem.

\section{Step 2. Form program team}

Identify stakeholders, interest groups, and affected people. Consider marginalized or ignored people and groups.

Invite important, interested, and affected people to participate.

Develop an active group of diverse people to serve as an advisory group and link to others.

Step 3. Build collaboration

Implement conflict resolution techniques to build trust, collaboration, consensus, and commitment within team.

Conflict resolution techniques may be required throughout process

\section{Step 4. Define framework}

Through preliminary assessment of issues using focus groups, key informant interviews, public forums, and meetings, identify important environmental, social, and economic elements.

Identify program scale and boundaries (environmental, social, economic).

Step 5. Establish vision, goals, and objectives

Invite diverse people to participate in forums and workshops.

Use conflict resolution, brainstorming, and focus group techniques to build collaboration and solicit ideas from people.

Program team formalizes vision, goals, and objectives using ideas from diverse groups of people.

\section{Step 6. Collect data}

Include environmental, social, and economic data.

Contact experienced individuals and groups.

tion, helping to increase community action and aiding the process of community (Wilkinson 1991). It also ensures higher rates of success since the program has been accepted by diverse groups of people.

\section{Ecosystem Principles}

Conservation, sustainability, diversity, and connectivity are guiding principles, and are defined both ecologically and humanistically (USDA Forest Service 1994). Conservation means nondegradation of natural systems and involving people in environmental stewardship. Sustainability is the commitment to protect, restore, and manage natural systems to remain viable and healthy indefinitely. In human terms, sustainability is the achievement of a clean and safe environment, guided growth, connectivity with the past, a functional city form, an optimal level of public services, and a high degree of interaction and control in local decision making. Diversity is characterized by
Step 7. Synthesize data

Prepare analysis of data thatidentifies critical patterns, processes, and linkages.

Organize using GIS and other technologies.

Step 8. Evaluate vision, goals, and objectives

Provide vision, goals, and objectives to public and stakeholders for evaluation and comment.

Evaluate merits of goals and objectives against synthesized data and public feedback.

Program team selects preferred goals and objectives.

Step 9. Implement

Develop work plans, budgets, and timetables.

Assign work responsibilities and develop funding alternatives.

Continue opportunities for education and involvement of people.

Step 10. Monitor and evaluate

Use written and oral surveys, focus groups, and success/failure to evaluate progress against goals and objectives.

Keep diverse people informed of success and involved in changes

Step 11. Manage and adapt

Adapt if not working or to meet changing circumstances.

New efforts in contacting and involving people and groups may be needed.

New information may be needed.
Table 2. Differences between EBAs and traditional land-use planning.

- EBAs are aggressive in including and empowering diverse people in decision making, including those marginalized and ignored.

- EBAs recognize the natural environment as a crucial component in community development.

- EBAs strive to build intermunicipal cooperation and partnership.

- EBAs recognize natural rather than jurisdictional boundaries.

- EBAS work to resolve conflict and build collaboration.

an optimal variety of life and increased inclusiveness, interaction, and empowerment of people. Connectivity refers to networks of viable natural systems and interconnecting habitats, as well as cooperating partnerships among individuals, municipalities, and organizations. 


\section{Using EBA to Support Traditional Land-Use Planning}

An EBA can be used to support the ability of traditional land use planning to conserve greenspace by recognizing and including important natural systems in decision making, working to build intermunicipal cooperation, and increasing the awareness and involvement of diverse people. Some of the tools that can be used to accomplish this include focus groups, empowerment, building public/private teams, multijurisdictional planning, natural resource inventories, inclusive comprehensive plans, and progressive ordinances.

Focus groups. Focus groups are a low-cost means of involving people and collecting information on an issue. As the name suggests, a focus group is an informal discussion among eight to ten people who examine a topic on their own terms with guidance from someone skilled in moderating group interaction.

Empowerment. Public issues forums, committee work, participatory research, education, and volunteerism are ways to empower people.

Teams. Today it is possible to cultivate major corporate and private foundation support for planning, land acquisition, and educational programs. Land conservancies and municipalities have worked together to plan for and acquire greenspace.

Multijurisdictional planning. Adjoining municipalities have formed powerful partnerships with joint comprehensive planning and joint power agreements.

Natural resource inventories. To recognize the natural environment in planning efforts, the following resource categories should be used: significant wildlife habitat, scenic areas, river and riparian corridors, recreational resources, productive agricultural and forest resources, woodlands and natural areas, special or unique landscapes, wetlands, floodways and floodplains, historical and cultural resources, vulnerable landscapes and soils, moderate and steep slopes, viewsheds, contiguous blocks, and corridors for the passage of wildlife and other natural elements (Boughton et al. 1991; Falk et al. 1992; Arendt 1997). Further, a geographic information system (GIS) can be used to help organize and monitor such information.

Inclusive comprehensive plans. Such plans recognize natural systems as a core community value by including open- or greenspace and conservation chapters and recognizing natural categories on official maps.

Progressive ordinances. Zoning that allows for conservation subdivisions and other development can be used to encourage the conservation of greenspace in development. Subdivision ordinances can be crafted to mandate the completion of natural resource inventories, allow for conservation subdivisions, mandate dedication of greenspace in development, mandate inlieu fees to be paid to acquire off-site greenspace, and to protect woodlands, steep slopes, watercourses, and other resources. Together, these policy vehicles provide for innovative and site-specific grading and site plans.

\section{A Small-Scale EBA Example}

Goals of conservation subdivision design (Arendt 1994, 1997) include modifying traditional ordinances to allow for creativity and flexibility in design, understanding the natural features of a site, conservation of the most sensitive natural features such as wetlands, and keeping fragmentation and isolation of the natural environment to a minimum by considering individual subdivisions as a part of a comprehensive plan.

As illustrated in Figures 1, 2, and 3, there is a five-step approach to designing conservation subdivisions: 1) developing a context map that identifies the subject property in relation to surrounding landscapes; 2) identifying conservation areas by resource inventory and site analysis and placing such areas as woodlots, riparian areas, and landmark trees on a detailed features map; 3) locating potential house sites that preserve conservation areas but allow for full density; 4) aligning streets in the optimal manner to access homes; and 5) drawing lot lines. This planning and design process identifies the important natural features of a site and clusters homes and infrastructures to preserve them.

\section{A Broad-Scale EBA Example}

An ecosystem approach continues to be used places to consider broad-scale environmental and social issues caused by population growth. Examples include the Phalen Chain of Lakes Watershed Comprehensive Natural Resources Plan in Minnesota (USDA Forest Service 1994) and the Keuka Lake Watershed Program in New York State (Cornell University Program 


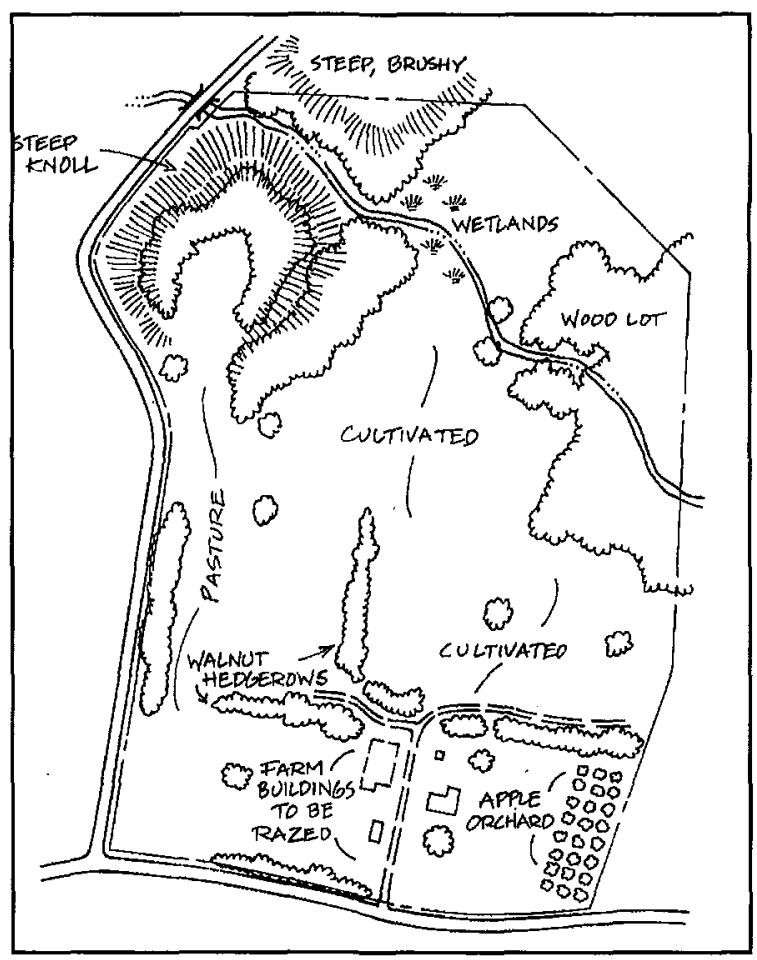

Figure 1. A natural resource inventory identifies all important natural components of a site.

on Environmental Conflict Management 1998). In addition to other similarities identified in Table 3 in both of these watersheds, cooperation and partnerships continue to be developed among local people and governments, businesses, and county, state, and federal agencies. These programs share a goal: to demonstrate that through an organized process, the conflict surrounding broad-scale environmental issues can be resolved in ways that enable a variety of diverse interests to work together to manage community development in a watershed while conserving natural resources.

\section{Problems Using EBA}

Much scientific bantering has occurred over what ecosystems are, whether boundaries can be placed around them, and how data collection, monitoring, modeling, and other operationalizing aspects can take place. Ecosystem planning processes are criticized for placing the nonhuman biological and physical attributes of nature ahead of goals for human advancement. As a process that seeks to under-

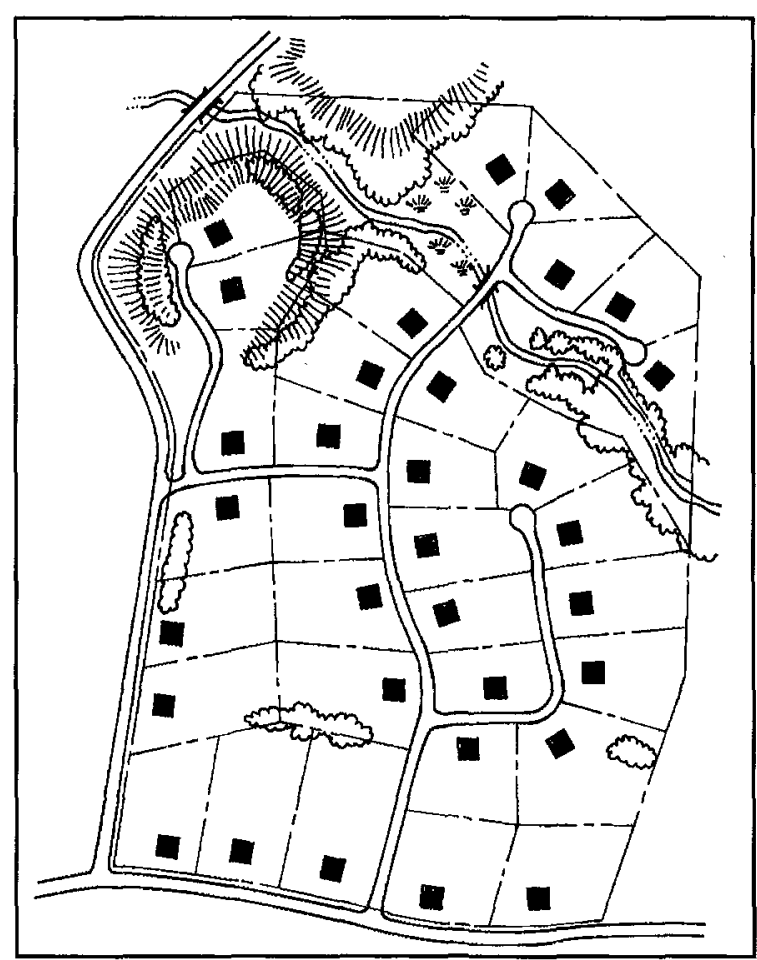

Figure 2. Traditional subdivision design provides for the maximum number of minimum-sized lots.

Table 3. Similarities of successful ecosystem approaches.

- conflict resolution, listening, trust, and collaboration

- understanding, support, and empowered citizen participation

- informed and committed leaders

- commitment from and involvement of businesses and agencies

- public/private partnerships

- patience and long time frames

stand and monitor land use, EBA has been perceived as a threat to the unlimited use of private property. Chaplin and Kaiser (1979) concluded that an ecosystem approach to land-use planning cannot yet be used by most municipal planning agencies because of its stringent and expensive demands for staffing, data collection, and monitoring. Like any other planning process, EBA requires funding, leadership, and staffing. Furthermore, like past attempts at regional planning, the ability of an EBA to break through structural barriers (such as the autonomy and self- 


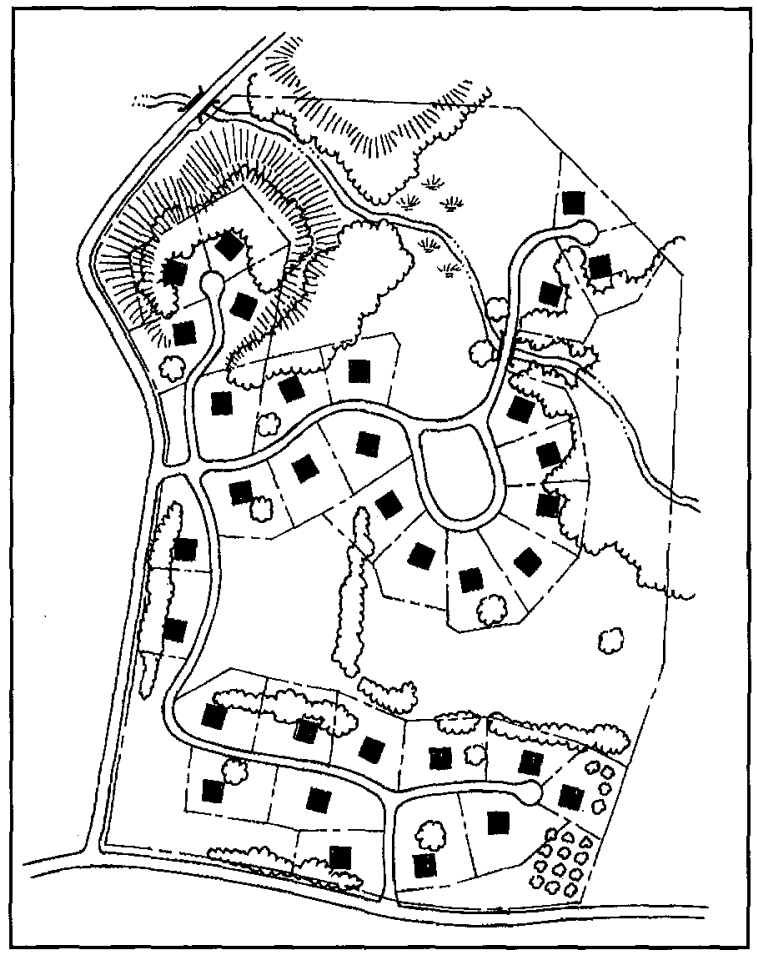

Figure 3. Conservation subdivision design can protect development densities and natural components.

sufficiency of local governments) to bring jurisdictions and conflicting stakeholders to consensus has been questioned. Conflict over specific conservation, land-use, and regulation objectives is common, and intermunicipal connections and cooperation remain rare today.

\section{CONCLUSION}

Findings from residential preference and values surveys continue to reveal veneration for the small town community (Willits et al. 1995). Greenspace is an important component of this community, but today both local and multijurisdictional planning efforts are required to conserve it. In such efforts, land-use planning and regulation must consider both individual and contextual elements. Individually, municipalities must have sound land-use planning and regulation and involved, informed citizens and leaders. Success in conserving greenspace depends upon local planning departments understanding and using the fundamentals of land use planning. When local governments are provided support by state-enabling legislation, grants, mentoring programs, education, and technical assistance to use the planning fundamentals of subsidies and incentives, taxation, regulation, public acquisition, and education, broader-scale efforts may become more realizable.

Realistically, greenspace cannot be conserved across jurisdictional lines without cooperation from multiple jurisdictions and planning agencies. Contextually, multiple municipalities, agencies, organizations, and stakeholders are brought together in a partnership, or a federation, that works towards mutually agreed-upon planning goals. The values of local autonomy and self-sufficiency, although important, can be a weakness in a world of increasing economic and environmental interdependencies. Local autonomy must be balanced with actions that show concern for others and a commitment to broader social and environmental values to conserve large and contiguous greenspace systems.

To help promote intermunicipal cooperation, leaders must be educated on the social and environmental benefits of working together in land-use planning and greenspace conservation. They also must be provided opportunities through multijurisdictional committees, such as watershed commissions, to become aware of and discuss shared issues and opportunities. Such activities can help leaders and others understand how public and private interests can be enmeshed in both local and regional interests.

Community foresters and arborists can help support greenspace conservation by understanding and becoming involved in land-use planning and decision making through actions suggested in Table 4. In light of the velocity and nature of current growth, it is im-

Table 4. How arborists and community foresters can become involved in land-use planning.

- Volunteer to serve on planning commissions, environmental advisory committees, and ad hoc committees.

- Become familiar with existing and proposed comprehensive plans and development ordinances.

- Become familiar with proposed developments and participate in and attend public hearings.

- Write letters to the editor and help organize concerned people.

- Support local conservancies and environmental groups.

- Work with cooperative extension to provide workshops and educational materials. 
portant that community foresters and arborists think more broadly about the natural environment and the people who interact with it. As society continues to grow, we need to broaden our conservation ethic to consider the impact of subdivision and other land uses on the natural environment.

\section{LITERATURE CITED}

Arendt, R. 1994. Designing Open Space Subdivisions: A Practical Step-by-Step Approach. Natural Lands Trust, Media, PA.

Arendt, R. 1997. Growing Greener: A Conservation Planning Workbook for Municipal Officials in Pennsylvania. Natural Lands Trust, Media, PA.

Boughton, J., J. Horton, E. Leary, and S. Sinclair. 1991. Planning for the Future Forest: A Supplement to the Planning Manual for Vermont Municipalities. University of Vermont Extension Service, Burlington, VT.

Center for the Study of Law and Politics. 1991. Open Space: Preservation and Acquisition. Center for the Study of Law and Politics, San Francisco, CA.

Chaplin, F, and E. Kaiser. 1979 (3rd ed.). Urban Land Use Planning. University of Illinois Press, Urbana, IL.

Clark, J., N. Matheny, G. Cross, and V. Wake. 1997. A model of urban forest sustainability. J. Arboric. 23(1):17-30.

Cornell University Program on Environmental Conflict Management. 1998. Keuka Lake watershed program. In Conflict and Collaboration in Community and Environmental Decision-Making Training Workbook. Cornell University, Ithaca, NY.

Dwyer, J., H. Schroeder, and P. Gobster. 1992. The significance of urban trees and forests: Toward a deeper understanding of values. J. Arboric. 17(10):276-284.

Falk, L., S. Harper, and E. Rankin. 1992. The Northern Forest Lands Study of New England and New York. USDA Forest Service, Rutland, VT.

Freudenburg, W., and K. Keating. 1985. Applying sociology to policy: Social science and the environmental impact statement. Rural Sociol. 50(4):578-605.

Hawley, A. 1950. The Changing Shape of Metropolitan America: Decentralization Since 1920. The Free Press, Glencoe, $1 \mathrm{~L}$.

Harper, J., and L. Propst. 1990. Creating Successful Communities: A Guidebook to Growth Management Strategies. The Island Press, Washington, DC.

Hylton, T. 1995. Save Our Land, Save Our Town: A Plan For Pennsylvania. Strine Printing Co., York, PA.

Lemonides, J., and A. Young. 1978. Provision of open space in urban areas: Determinants, obstacles, and incentives. Am. Inst. Plann. 44(July):286-296.
Lewis, P. 1993. The Urban Invasion of Rural America: Emergence of the Gallactic City. Department of Geography, The Pennsylvania State University, University Park, PA.

Luloff, A. E., and D. Hodges. 1992. Attitudes and bureaucrats: Assessing the representativeness of local officials in New Hampshire. Rural Sociol. 57(3): 381-395.

Luloff, A. E., K. P. Wilkinson, M. R. Schwartz, J. C. Finley, S. B. Jones, and C. R. Humphrey. 1993. Pennsylvania Forest Stewardship Program's Media Campaign: Forest Landowners' and the General Public's Opinions and Attitudes. Final Report to the USDA Forest Service.

McHarg, I. 1992. Design With Nature. Wiley, New York, NY.

McPherson, G. 1998. Atmospheric carbon dioxide reduction by Sacramento's urban forest. J. Arboric. 24(4):215-223.

Miller, R. 1998. Urban Forestry: Planning and Managing Urban Greenspaces (2nd ed.). Prentice-Hall, Upper Saddle River, New Jersey.

National Park Service. 1992. Economic Impacts of Protecting Rivers, Trails, and Greenway Corridors: A Resource Book. Rivers, Trails and Conservation Assistance Program, National Park Service, Washington, DC.

Simon, E., A. Gallon, and S. Eisner. 1993. The Urban Pattern. Van Nostrand Reinhold, New York, NY.

Simpson, J. 1998. Urban forest impacts on regional cooling and heating use: Sacramento County case study. J. Arboric. 24(4):201-214.

USDA Forest Service. 1993. New York-New Jersey Highlands Regional Study. USDA State and Private Forestry, Northeastern Region, Radnor, PA.

USDA Forest Service. 1994. An Ecosystem-Based Approach to Urban and Community Forestry: An Ecosystem Manager's Workbook. USDA State and Private Forestry, Northeastern Region, Radnor, PA.

Wilkinson, K. P. 1991. The Community in Rural America. Greenwood Press, New York, NY.

Willits, F, J. Janota, and L. Singletary. 1995. Centre County: Today and Tomorrow: Public Perceptions. Department of Agricultural Economics and Rural Sociology, The Pennsylvania State University, University Park, PA.

Wilson, W. 1989. The City Beautiful Movement. The Johns Hopkins University Press, Baltimore, MD.

Yaro, D. J., R. Arendt, H. L. Dodson, and E. A. Brabec. 1993. Dealing With Change in the Connecticut River Valley: A Design Manual for Conservation and Development. Massachusetts Department of Environmental Management. 
Acknowledgments. Thanks to Dr. Henry Gerhold and Dr. Stan Lembeck, Penn State University, for their contributions to this article.

\section{${ }^{1 *}$ Instructor and Program Coordinator, Community Forestry \\ The Pennsylvania State University \\ School of Forest Resources \\ 108 Ferguson Building \\ University Park, PA 16802}

\author{
${ }^{2}$ Professor, Rural Sociology \\ The Pennsylvania State University \\ University Park, PA
}

\section{*Corresponding author}

Résumé. Pour supporter et promouvoir le rôle de la foresterie communautaire dans les grands enjeux environnementaux, une «approche de base d'écosystème" à la foresterie locale a été développée par le Service forestier américain en 1994. Lapproche de base d'écosystème est un processus de planification pour la conservation, le maintien, la diversité et l'interrelation de la forêt urbaine. Les principes directeurs sont interprétés à la fois sur une base sociale et écologique. La planification du territoire et la réglementation ont été utilisés depuis le début du 20 e siècle. pour guider l'expansion et la préservation des espaces verts, cependant que la planification environnementale rencontre plusieurs obstacles dans une arène compétitive et conflictuelle sur l'usage du territoire. Même si les forestiers locaux peuvent être impliqués dans la planification du territoire et l'implantation d'approches d'écosystèmes au travers de cette méthode, il demeure toujours une question encore non étudiée à propos de ce nouveau processus de planification: est-ce que l'approche de base d'écosystème peut être employée pour conserver les espaces verts après que les efforts traditionnels d'utilisation du territoire aient échoué?
Zusammenfassung. Um die Rolle der kommunalen Forstwirtschaft bei größeren umweltpolitischen Fragen stärker zu unterstützen und zu verstärken, wurde ein Annäherungsversuch an die kommunale Forstwirtschaft (EBA) auf der Basis von Ökosystemen entwickelt (USDA Forest Service 1994). In diesem Versuch wurde der Prozeß der Planung von Erhaltungsmaßnnahmen, Naturverjüngung, Artenvielfalt und innerstrukturelle Verbindung aufgezeigt. Diese Grundleitlinien wurden soziologisch und ökologisch interpretiert. Die Landnutzungsplanung und die Regulation werden seit dem frühen zwanzigsten Jahrhundert genutzt, um das Wachstum und den Erhalt von Grünräumen zu leiten, aber die ökologische Planung wird immer mit zahlreichen Hindernissen aus der Arena der stets konkurierenden Landnutzung konfrontiert. Obwohl kommunale Forstleute in die Landnutzungsplanung involviert werden und sie durch EBA einige veränderungen in den Ökosystemen zur Ausführung bringen können, bleibt doch immer noch die Frage über diesen neuen Planungsprozeß offen: kann EBA genutzt werden, um Grünrãume zu erhalten, wenn traditionelle Landnutzungspläne versagt haben?

Resumen. Con el fin de apoyar y promover el papel de la comunidad forestal en grandes temáticas ambientales, se desarrolló la Aproximación Basada en el Ecosistema (EBA, por sus siglas en inglés) para la comunidad forestal (USDA Forest Service 1994). EBA es un proceso de planeamiento para la conservación, sustentabilidad, diversidad, y conectividad del bosque urbano. Los principios guía son interpretados tanto social como ecológicamente. El planeamiento y la regulación del uso del suelo han sido usados desde el principio del siglo veinte para guiar el crecimiento y la preservación del espacio verde, pero el planeamiento ambiental se enfrenta a numerosos obstáculos en el campo de un uso del suelo competitivo y litigioso. $\mathrm{Si}$ bien los forestales comunitarios pueden llegar a involucrarse en el planeamiento del uso del suelo e instrumentación de acercamientos al ecosistema a través de EBA, hay aún una cuestión acerca de este nuevo proceso de planeamiento que permanece sin estudio: ipuede EBA ser usado para conservar el espacio verde después que los sistemas tradicionales de uso del suelo han fallado? 